\title{
Bacterial Populations Associated with Rice Seed in the Tropical Environment
}

\author{
B. Cottyn, E. Regalado, B. Lanoot, M. De Cleene, T. W. Mew, and J. Swings
}

First, second, and fifth authors: Entomology and Plant Pathology Division, International Rice Research Institute, MCPO Box 3127,1271 Makati City, Philippines; and third, fourth, and sixth authors: Laboratorium voor Microbiologie, Universiteit Gent, K. L. Ledeganckstraat 35, B9000 Gent, Belgium.

Accepted for publication 10 November 2000.

\begin{abstract}
Cottyn, B., Regalado, E., Lanoot, B., De Cleene, M., Mew, T. W., and Swings, J. 2001. Bacterial populations associated with rice seed in the tropical environment. Phytopathology 91:282-292.

During the 1995 wet season, harvested rice seed was collected from farmers' fields at different locations in Iloilo, Philippines. Bacterial isolations from crushed seed yielded 428 isolates. The isolates were characterized by BOX-polymerase chain reaction fingerprinting of total genomic DNA and represented 151 fingerprint types (FPT). Most FPTs were found on a single occasion, although matching fingerprints for iso-

GN/GP MicroPlates and API 20E/50CHE systems. The predominant bacteria were Enterobacteriaceae (25\%), Bacillus spp. (22\%), and Pseudomonas spp. (14\%). Other bacteria regularly present were identified as Xanthomonas spp., Cellulomonas flavigena, and Clavibacter michiganense. Of the total number of isolated bacteria, $4 \%$ exhibited in vitro antifungal activity against Rhizoctonia solani or Pyricularia grisea. Two percent of isolates were pathogens identified as Burkholderia glumae and Burkholderia gladioli. Five percent of isolates induced sheath necrosis on only 50 to $90 \%$ of inoculated plants and were related to Bacillus pumilus, Paenibacillus spp., Pseudomonas spp., and Pantoea spp.
\end{abstract} lates from different samples also were found. Identifications were made by cellular fatty acid methyl ester analysis and additional use of Biolog
Additional keywords: coryneform bacteria, nonpathogenic xanthomonads.
Rice (Oryza sativa L.) is the primary food grain consumed by almost half of the world's population, making it the most important food crop currently produced. Current integrated pest management (IPM) strategies in tropical rice production emphasize the use of host-plant resistance, cultural practices, and biological control for maintaining low pest populations. The diverse communities of nonpathogenic, plant-associated microorganisms are a largely untapped resource for protection against plant disease (6). Microbial biological control of plant diseases is often crop- and site-specific; therefore, it is also believed that its real potential may be in the use of many different locally adapted strains (7). Understanding the bacterial community composition on rice seed would be a first step toward exploiting bacteria for biological control.

The seed, being the planting material and the carrier of the genetic potential of the crop, is considered the starting point for achieving sustainable high yields. However, in contrast to the rice rhizosphere, about which interest in biological nitrogen fixation has led to ample characterization of free-living and endophytic diazotrophic bacteria $(30,41)$, little is known about the composition of bacterial communities of rice seed. Characterization of bacterial populations on the rice phylloplane has commonly been restricted to those bacteria that cause disease $(2,16,26,43,50)$, in much the same way that studies on rice seed microflora have been confined to seedborne pathogens $(10,29,39)$.

Several studies have demonstrated the usefulness of repetitive sequence-based polymerase chain reaction (rep-PCR) to fingerprint a large variety of bacteria and to study microbial diversity in natural ecosystems $(21,47)$. The rep-PCR method (referring collectively to REP-, ERIC-, and BOX-PCR) uses oligonucleotide

Corresponding author: T. W. Mew; E-mail address: T.Mew@ cgiar.org

Publication no. P-2001-0109-01R

(C) 2001 The American Phytopathological Society primers matching interspersed repetitive DNA sequences and the rep-PCR to generate a genomic fingerprint that can distinguish bacteria at a fine level. These interspersed repetitive elements are conserved in diverse genera of bacteria and, therefore, enable single primer sets to be used for DNA fingerprinting of many different microorganisms $(21,47)$. In the present study, we used the BOXA1R primer corresponding to the boxA-subunit sequences (22) for PCR-based DNA fingerprinting of bacteria isolated from rice seed. In addition, whole-cell fatty acid analysis, the Biolog MicroPlate system (Biolog Inc., Hayward, CA), and API systems (BioMérieux, La Balme-les-Grottes, France) were used for species identification of the isolates. These phenotypic typing methods are relatively simple and automated, and have been widely used both for taxonomic studies and identification $(11,12,27,40)$. However, the resolution level of these techniques depends on the group of bacteria studied (48).

The purpose of this study was to (i) assess the genetic diversity of the culturable aerobic bacterial isolates of rice seed by BOXPCR genomic fingerprinting; (ii) identify the strains represented by defined BOX-PCR fingerprint types; (iii) classify the isolates into functional groups of saprophytic, antagonistic, and pathogenic bacteria; and (iv) assess the influence of seed germination on the composition of bacterial communities.

\section{MATERIALS AND METHODS}

Bacterial strains. For each BOX-PCR fingerprint type (FPT) defined in this study, a representative strain has been deposited in the Belgian Coordinated Collections of Microorganisms/ Laboratorium Microbiologie Gent (BCCM/LMG) culture collection. In addition, genomic DNA of 137 reference strains was included in the BOX-PCR fingerprinting. These reference strains were obtained from the BCCM/LMG culture collection and mainly consisted of type strains of various species of the genera Acidovorax, Acinetobacter, Agrobacterium, Aureobacterium, Ba- 
cillus, Burkholderia, Cellulomonas, Chryseobacterium, Clavibacter, Curtobacterium, Enterobacter, Erwinia, Flavimonas, Klebsiella, Pantoea, Pseudomonas, Salmonella, Sphingomonas, and Xanthomonas.

Isolation of bacteria from seed. During the 1995 wet season, $1-\mathrm{kg}$ samples of harvested rice were purchased from 11 farmers in Iloilo (Philippines). An overview of the collected samples, their respective cultivar, and location of origin is given in Table 1. From each of the 11 samples, a 10-g batch of seed was processed. The seed was partially crushed (until approximately $80 \%$ of the seed was broken) with a sterilized mortar and pestle and suspended in $100 \mathrm{ml}$ of sterile phosphate-buffered saline solution (PBS; $137 \mathrm{mM} \mathrm{NaCl}, 2.7 \mathrm{mM} \mathrm{KCl}, 0.01 \mathrm{M} \mathrm{Na}_{2} \mathrm{HPO}_{4}, 1.8 \mathrm{mM}$ $\mathrm{KH}_{2} \mathrm{PO}_{4}, \mathrm{pH} 7.4$ ) with $0.025 \%$ Tween 20 (Sigma-Aldrich, St. Louis). The seed suspension was incubated for $2 \mathrm{~h}$ at $4^{\circ} \mathrm{C}$. Then, $100 \mu \mathrm{l}$ of 10 -fold serial dilutions $\left(10^{-2}, 10^{-3}\right.$, and $\left.10^{-4}\right)$ of the suspension in sterile saline $(0.85 \% \mathrm{NaCl})$ was plated in duplicate on King's medium B (KMB) (14) and glucose yeast chalk agar (GYCA) (37) supplemented with $0.01 \%$ cycloheximide (SigmaAldrich). The duplicate dilution plates were incubated at $28^{\circ} \mathrm{C}$ for 4 days. All visually distinct colony types, with two to three arbitrarily picked for abundant types, were isolated from each sample. The isolates were purified on nutrient agar (NA; Difco Laboratories, Detroit) and maintained at $-70^{\circ} \mathrm{C}$ in nutrient broth (NB; Difco Laboratories) with $15 \%$ glycerol.

To assess the impact of seed germination on the composition of bacterial communities, additional isolations were done from soaked germinated seed from each sample. Seed (10 g) was incubated in $50 \mathrm{ml}$ of sterile distilled water in plastic germination boxes ( 14 by 17 by $4.5 \mathrm{~cm}$ ), precleaned with $10 \%$ sodium dodecyl sulfate (SDS) and $70 \%$ ethanol, for 3 days at $28^{\circ} \mathrm{C}$ until $\approx 40 \%$ of the seed was germinated. Germination was indicated by the appearance of the white tip of the coleoptile. On the fourth day, an additional $50 \mathrm{ml}$ of sterile distilled water with $0.025 \%$ Tween 20 was added, and the germination boxes were shaken at $50 \mathrm{rpm}$ on an orbital shaker for $1 \mathrm{~h}$ at room temperature. Portions of $100 \mu \mathrm{l}$ of 10 -fold serial dilutions $\left(10^{-4}, 10^{-5}\right.$, and $\left.10^{-6}\right)$ of the seed soak in sterile saline $(0.85 \% \mathrm{NaCl})$ were plated in duplicate on $\mathrm{KMB}$ and GYCA supplemented with $0.01 \%$ cycloheximide. The plates were incubated at $28^{\circ} \mathrm{C}$ for 4 days. Picking and purification of colonies was performed as described above.

Remaining seed of the 11 samples was stored at $4{ }^{\circ} \mathrm{C}$ in the Seed Health Unit of the International Rice Research Institute (IRRI), Los Baños, Philippines. BOX-PCR fingerprinting was performed for all picked colonies from all crushed seed samples, and from two arbitrarily chosen germinated seed samples.

Pathogenicity tests. All bacteria isolated from crushed seed were tested for pathogenicity by inoculation of 21-day-old rice seedlings of cv. IR24 grown in the greenhouse under natural light with day and night temperatures of $\approx 35$ and $25^{\circ} \mathrm{C}$, respectively, and with relative humidity ranging from 40 to $65 \%$. Seed was disinfected for $5 \mathrm{~min}$ in $70 \%$ ethanol and rinsed five times with sterile distilled water, then soaked for $12 \mathrm{~h}$ under running tap water and planted in autoclaved soil. For each bacterial isolate, four seedlings were inoculated by injecting the culm $\approx 2 \mathrm{~cm}$ above the soil with $1 \mathrm{ml}$ of an overnight-grown $\mathrm{NB}$ culture $(\approx 3 \times$ $\left.10^{8} \mathrm{CFU} / \mathrm{ml}\right)$. Plants inoculated with sterile NB and cultures of known virulent strains $(X$. oryzae pv. oryzae strain PXO81, and Burkholderia glumae strain 2056) served as negative and positive control, respectively. The plants were examined for symptoms 3 and 10 days after inoculation. Plants were scored as negative when no obvious symptoms or a hypersensitive-like reaction localized at the point of inoculation occurred. Elongation of a brown necrotic zone of tissue away from the point of inoculation, often extended up to the third leaf, was scored as a positive reaction. Isolates that produced a positive reaction on at least two out of four seedlings in the first experiment were inoculated two more times on four plants in a second and third experiment.
Bacteria were re-isolated from selected plants to confirm that symptoms were caused by the inoculated isolate. The pathogenic isolates were differentiated on the basis of the consistency of the caused reaction between the three inoculation experiments. Bacterial isolates were considered pathogens if all plants inoculated showed a positive reaction; whereas, isolates that caused symptoms on at least $50 \%$ of inoculated plants in the three experiments were considered pathogens with low disease potential.

Screening for antifungal activity in vitro. All bacteria isolated from crushed seed were tested by the dual culture method as previously described (24) for antagonistic activity against four rice fungal pathogens: Rhizoctonia solani, Pyricularia grisea, Sarocladium oryzae, and Fusarium moniliforme. Cultures of the fungal pathogens collected from rice in the Philippines were maintained at the IRRI. Five mycelial plugs $(5 \mathrm{~mm}$ in diameter) were taken from an actively growing culture of $R$. solani on potato dextrose agar (PDA; $200 \mathrm{~g}$ of potato, $20 \mathrm{~g}$ of dextrose, and $18 \mathrm{~g}$ of agar per liter). One plug was placed at the center and four plugs at opposite sides toward the edge of the plate on pigment production medium (PPM; $20 \mathrm{~g}$ of proteose peptone, $20 \mathrm{~g}$ of glycerol, $5 \mathrm{~g}$ of $\mathrm{NaCl}, 1 \mathrm{~g}$ of KNO3, and $15 \mathrm{~g}$ of agar per liter, $\mathrm{pH}$ 7.2). Four bacterial cultures, grown for $48 \mathrm{~h}$ on PPM, were placed between the four peripheral agar plugs of $R$. solani. For antagonism tests against Pyricularia grisea, Sarocladium oryzae, and Fusarium moniliforme, $50 \mathrm{ml}$ of an aqueous conidial suspension (50,000 conidia per $\mathrm{ml}$ ) of each fungal pathogen was added to 1 liter of melted PPM at $45^{\circ} \mathrm{C}$. The inoculated PPM was poured into petri plates and allowed to congeal for $4 \mathrm{~h}$, after which bacterial isolates to be tested were placed in four equidistant places in the plates. Each fungal-bacterial combination was replicated three times. All dualculture plates were incubated at $28^{\circ} \mathrm{C}$ for 2 to 3 days and scored for inhibition of fungal growth. The diameter of the inhibition zone around the bacterial colony was measured.

DNA isolation. Bacteria were grown in $8.0 \mathrm{ml}$ of $\mathrm{NB}$ on a rotary shaker at $150 \mathrm{rpm}$ for $24 \mathrm{~h}$ at $28^{\circ} \mathrm{C}$. Extraction of total DNA was done as described previously (13). The DNA concentrations were estimated visually by comparison with $\lambda$ DNA standards in an agarose gel.

BOX-PCR fingerprinting. The primer BOXA1R [5'-CTACGGCAAGGCGACGCTGACG-3'] sequence corresponding to BOXA, a subunit of the BOX element (22), was synthesized by Operon Technologies Inc. (Alameda, CA). Each 25- $\mu$ l PCR reaction contained $2 \mu \mathrm{M}$ BOXA1R primer, $\approx 40$ to $80 \mathrm{ng}$ of genomic DNA, $1.25 \mathrm{mM}$ each dNTP (United States Biochemical, Cleveland), 2 units of AmpliTaq DNA polymerase (Pharmacia Biotech, Asia Pacific, Hong Kong), 10\% (vol/vol) DMSO (SigmaAldrich), and bovine serum albumin at $0.16 \mathrm{mg} / \mathrm{ml}$ (Boehringer Mannheim, Far East, Singapore) in 0.5× Gitschier buffer (15). PCR amplifications were performed in a DNA thermal cycler (480; Perkin-Elmer, Norwalk, CT) with an initial denaturation at $95^{\circ} \mathrm{C}$ for $7 \mathrm{~min}$, followed by 30 cycles of denaturation at $94^{\circ} \mathrm{C}$ for $1 \mathrm{~min}$, annealing at $53^{\circ} \mathrm{C}$ for $1 \mathrm{~min}$, extension at $65^{\circ} \mathrm{C}$ for $8 \mathrm{~min}$, and a final extension at $65^{\circ} \mathrm{C}$ for $15 \mathrm{~min}$. Aliquots $(7 \mu \mathrm{l})$ of amplified PCR products were separated by gel electrophoresis on gels composed of $0.8 \%$ Synergel (Diversified Biotech, Boston, MA) and $0.8 \%$ agarose (United States Biochemical) in $0.5 \times$ Tris-borate-EDTA (TBE) (35) at $75 \mathrm{~V}$ for $14 \mathrm{~h}$. As standard, a 1-kb size marker (Life Technologies, Pacific, Hong Kong) was run in the second, sixteenth, and thirtieth lane. The gels were stained with ethidium bromide and photographed on an UV transilluminator with Polaroid Type 55 film (Polaroid Corp., Cambridge, MA). The photographs were scanned on a flatbed scanner (Sharp JX610) at 200 dots per inch (dpi) resolution. Normalization of BOXPCR patterns and cluster analysis was achieved with the commercially available GelCompar software (version 4.0; Applied Maths, Kortrijk, Belgium). Similarity between BOX-PCR fingerprints was calculated by the Pearson correlation coefficient, and clustering was done by the unweighted pair group method using 
arithmetic averages (UPGMA). Additional interpretation of the DNA fingerprints was carried out by visual examination. We defined an FPT as a set of strains with identical or nearly identical BOX-PCR DNA patterns. Patterns were considered nearly identical when variation was limited to two or three faint DNA fragments.

Reproducibility of DNA fingerprints. The level of reproducibility of BOX-PCR fingerprinting was determined by including DNA of isolate G237 in each PCR assay; its resulting fingerprint was used as an internal standard during each electrophoresis run. Generated BOX-PCR fingerprints of examined isolates were repeated at least twice, and gel runs had been separated over a period of 9 months. Intergel reproducibility as derived from the similarity scale in the dendrogram generated by the UPGMA clustering analysis software of GelCompar was $89 \%$. Although this could be considered a rather low reproducibility, it was mainly attributed to differences in electrophoresis times and variations in background intensities because, visually, no differences in the obtained banding patterns could be seen. When reproducibility was determined by obtaining repeated patterns of six strains in three PCR experiments and amplification products were separated on the same gel, the intragel correlation between these patterns was above $93 \%$.

Phenotypic identification. The following features were examined for all isolates: description of colonial and cellular morphology, Gram stain, fluorescent pigment production on KMB, Kovac's oxidase reaction, nitrate reduction, and reaction on Hugh and Leifson's oxidation-fermentation medium $(17,37)$. Fatty acid methyl ester (FAME) analysis, in combination with Biolog and API-strips, was performed on at least two isolates per defined FPT unless the FPT was unique to a single isolate.

FAME analysis. All examined isolates were grown on trypticase soy agar (TSA) (BBL, Becton Dickinson Microbiology Systems, Cockeysville, MD) at $28^{\circ} \mathrm{C}$ for $24 \mathrm{~h}$. Extraction and preparation of the cellular fatty acid methyl esters were performed according to Sasser (36). FAMEs were analyzed with a HewlettPackard HP5890A gas-liquid chromatograph on a 5\% phenylmethyl silicone-coated glass capillary column. The generated profiles were identified by using the Microbial Identification System (MIS version 4.15; Microbial ID Inc., Newark, DE). The same software was also used for calculating the dissimilarity between profiles using the Euclidean distance coefficient, and for UPGMA clustering. The correlation between a profile from an unknown isolate and a library entry was expressed as a similarity index (SI) on a numeric scale of 0 to 1 . MIS identifications at the species level were considered reliable when the first choice had an SI value of $\geq 0.5$, and the numerical difference between the first and second choice SI value was $\geq 0.1$. Cellular fatty acid profiles of gramnegative and gram-positive isolates were clustered in distinct den-

TABLE 1. Rice seed lots collected during the 1995 wet-season harvest in Iloilo, Philippines

\begin{tabular}{|c|c|c|c|}
\hline$\overline{\text { Cultivar }}$ & Collection no. ${ }^{\mathrm{a}}$ & Field location & No. of isolates \\
\hline \multirow[t]{5}{*}{ IR64 } & $1-1$ & San Miguel & 25 \\
\hline & $2-7$ & San Miguel & 19 \\
\hline & $3-7$ & San Miguel & 22 \\
\hline & $10-1$ & Zarraga & 45 \\
\hline & $19-9$ & Ajuy & 41 \\
\hline \multirow[t]{2}{*}{ IR36 } & $23-7$ & Barotac Nuevo & 52 \\
\hline & $25-4$ & Concepcion & 47 \\
\hline IR38 & $14-8$ & Dingle & 43 \\
\hline IR60 & $20-6$ & Ajuy & 50 \\
\hline $\mathrm{RC} 14$ & $28-9$ & San Dionisio & 46 \\
\hline Bordagol & $30-8$ & San Dionisio & 38 \\
\hline
\end{tabular}

${ }^{a}$ Remnant seed from the collected seed lots are stored at the Seed Health Unit of the International Rice Research Institute, Los Baños, Philippines.

b All visually distinct colony types, with two to three arbitrarily picked for abundant types, were isolated. drograms. FAME clusters were arbitrarily delineated at approximately 12 Euclidean distance units. Only clusters containing at least three isolates (as the number of isolates per FPT had been determined by the comparison of BOX-PCR fingerprints) were assigned as a group in the generated dendrograms. Single or less than three delineated isolates were ranked as ungrouped. Duplicate analysis of individual isolates clustered at a level of less than 5 Euclidean distance units.

Biolog and API systems. Whenever automatic comparison of the generated fatty acid profiles to the commercial TSBA library (version 4.15; Microbial ID Inc.) failed to give a reliable identification, further identification was done using the Biolog GN/GP MicroPlate systems (Biolog Inc.). Isolates identified by Biolog with a low similarity coefficient as belonging to the Enterobacteriaceae were further investigated by API $20 \mathrm{E}$ and $50 \mathrm{CHE}$ galleries according to the manufacturer's instructions (API Systems, Biomérieux). Isolates for Biolog analysis were grown on TSA for $24 \mathrm{~h}$ at $28^{\circ} \mathrm{C}$. The Biolog MicroPlates were inoculated with a bacterial suspension in sterile saline $(0.85 \% \mathrm{NaCl})$, adjusted in density to the Biolog MicroPlate system's turbidity standard, and incubated for $24 \mathrm{~h}$ at $30^{\circ} \mathrm{C}$. The plates were read on an automated microplate reader, and results were analyzed with Microlog software (version 3.50).

SDS-polyacrylamide gel electrophoresis of whole cell proteins. Whole-cell protein profiles were generated for those isolates that were thought to belong to the genus Burkholderia. Cultivation of bacterial cultures, preparation of whole-cell protein extracts, and SDS-polyacrylamide gel electrophoresis (PAGE) were performed as described previously (32). The obtained protein profiles were visually compared with the patterns in the database of the genus Burkholderia created by Vandamme et al. (45).

\section{RESULTS}

A total of 428 bacterial isolates, consisting of 244 gram-negative and 184 gram-positive bacteria, were isolated from crushed seed of 11 farmers' rice seed samples. On the basis of BOX-PCR fingerprinting of genomic DNA, 82 FPTs were distinguished among the gram-negative bacteria and 69 FPTs among the grampositive bacteria. If isolates within one FPT can be considered members of a single population, then at least 151 bacterial populations occurred in the seed samples. No FPT was found in all 11 samples. The majority of FPTs $(64 \%)$ were found just once, with 76 of these 96 FPTs delineated for a single isolate. The remaining 55 FPTs were found in more than one sample. The BOX-PCR fingerprint patterns consisted of 10 to 23 PCR products ranging in size from $\approx 200 \mathrm{bp}$ to $4.5 \mathrm{~kb}$. Minimal to no BOX-PCR amplification was observed for $90 \%$ of isolates identified as Chryseobacterium indologenes and Acinetobacter spp. Isolates identified as Bacillus spp. (especially Bacillus cereus) often revealed a minimal BOX-PCR pattern of only one to six PCR products. Such minimal amplification patterns were also obtained from corresponding LMG reference strains.

Resolution level of the BOX-PCR technique. BOX-PCR genomic fingerprinting of $137 \mathrm{LMG}$ reference strains was used to determine the resolution level of the technique. The BOX-PCR technique clearly distinguished different species but the diagnostic value of the patterns (i.e., the degree of variability observed among multiple reference strains of a single species) varied according to species (data not shown). Within some species, nearly identical fingerprint patterns were produced for multiple reference strains: Burkholderia glumae (LMG 2196, LMG 10905, and LMG 10906), Burkholderia plantarii (LMG 9035 and LMG 10908), Pseudomonas luteola (LMG 5946 and LMG 7041), Pseudomonas tolaasii (LMG 2342 and LMG 6635), X. hyacinthi (LMG 7419 and LMG 8042), and Pantoea ananatis (LMG 2665 and LMG 2676). Within other species, polymorphic patterns sharing multiple bands of equal mobility could be distinguished: Pseudomonas 
fuscovaginae (pattern 1: LMG 2158 and LMG 2192, pattern 2: LMG 5097, pattern 3: LMG 5742), Pseudomonas viridiflava (pattern 1: LMG 5285t1, LMG 5285t2, and LMG 5400; pattern 2: LMG 2359), Acidovorax avenae spp. avenae (pattern 1: LMG 1806 and LMG 10904; pattern 2: LMG 2117), Pantoea agglomerans (pattern 1: LMG 1286, pattern 2: LMG 2595, pattern 3: LMG 2565 and LMG 2578), and Aureobacterium testaceum (pattern 1: LMG 16144, pattern 2: LMG 16344). Furthermore, high variability among multiple reference strains was observed within some species: Sphingomonas paucimobilis (pattern 1: LMG 11151, pattern 2: LMG 1227), Pseudomonas stutzerii (pattern 1: LMG 1228, pattern 2: LMG 11199), Pseudomonas fulva (pattern 1: LMG 11722, pattern 2: LMG 11723), Pseudomonas fragi (pattern 1: LMG 2191, pattern 2: LMG 5919), Pseudomonas putida (pattern 1: LMG 2257, pattern 2: LMG 5835), Bacillus pumilus (pattern 1: LMG 3455, pattern 2: minimal amplification of only six bands for LMG 10642), Bacillus megaterium (pattern 1: LMG 7127, pattern 2: LMG 7132, pattern 3: LMG 11162; all showing minimal amplification of 6 to 11 bands), and Brevibacillus laterosporus (pattern 1: a minimal pattern for LMG 16000 and LMG 6931, pattern 2: good amplification for LMG 6932). BOX-PCR of Bacillus cereus strains (LMG 6923, LMG 17605, and LMG 17613) produced only a single PCR product, distinctive for each reference strain.

Pathovars within the genera Pseudomonas and Xanthomonas were clearly differentiated by the BOX-PCR technique, although Pseudomonas marginalis pv. marginalis (LMG 2210) only differed in the presence of two additional bands from the pattern of Pseudomonas marginalis pv. alfalfae (LMG 2214). Polymorphism was observed within $X$. arboricola pv. pruni (pattern 1: LMG 854, pattern 2: LMG 860t1) and also, consistent with Louws et al. (19), within Pseudomonas syringae pv. syringae (pattern 1: LMG 2230 and LMG 2231, pattern 2: LMG 5570) and Pseudomonas syringae pv. oryzae (pattern 1: LMG 10917 and LMG 10920, pattern 2: LMG 10912 and LMG 10915). On the other hand, no polymorphism was observed between two strains of $X$. translucens $\mathrm{pv}$. graminis (LMG 713 and LMG 726).

At the subspecies level, distinct BOX-PCR fingerprint patterns were observed between Clavibacter michiganense subsp. insidiosum (LMG 3663) and Clavibacter michiganense subsp. michiganense (LMG 7333), consistent with Louws et al. (18). Generated BOX profiles of 12 strains belonging to the genera Clavibacter, Cellulomonas, Curtobacterium, Arthrobacter, and Aureobacterium were distinct but shared some bands in common.

Qualitative composition of bacterial communities of rice seed. The 428 bacteria isolated from the 11 crushed seed samples were analyzed by BOX-PCR fingerprinting of total genomic DNA. Isolates with a nearly identical BOX-PCR pattern were defined as one FPT and considered as representing one bacterial population. Consequently, fatty acid analysis was done on representative isolates for each BOX-PCR FPT. An abridged dendrogram obtained by UPGMA analysis of the whole-cell FAME patterns for the gram-negative bacteria is shown in Figure 1. The predominant gram-negative bacteria were Enterobacteriaceae, nonfluorescent Pseudomonas spp., and Xanthomonas spp. The Enterobacteriaceae were identified by FAME-MIS, in combination with Biolog and API galleries, as Pantoea spp., Enterobacter cloacae, Enterobacter sakazakii, Salmonella choleraesuis, and Kluyvera ascorbata (Table 2). The identification for many isolates, however, remained doubtful. A single isolate identified as Erwinia carotovora (now Pectobacterium carotovorum) remained ungrouped on the basis of FAME analysis. The other isolates formed seven distinct subgroups delineated at 10 Euclidean distance units within FAME group N8. Four subgroups were occupied by isolates identified as Pantoea spp. Enterobacterial isolates were found in nearly all samples, except sample 2-7. The BOXPCR fingerprinting differentiated 23 FPTs among the enterobacterial isolates. Six FPTs matched isolates found in four or more samples. Isolates within the two FPTs delineated for LMG 18570 and LMG 18571 were found in 8 of the 11 samples. The two FPTs, only dissimilar in the absence of one prominent band in the profile of LMG 18571, were highly similar to the pattern generated for the Pantoea stewartii subsp. stewartii-type strain LMG 2715 (previously Erwinia stewartii) (data not shown).

Nonfluorescent pseudomonads were differentiated by $17 \mathrm{BOX}$ PCR FPTs. Based on fatty acid analysis, two groups (N9 and N10) were delineated at 12 Euclidean distance units and one isolate (LMG 18604) remained ungrouped (Table 2). The isolates within the predominant FAME group N10 tightly grouped together at less than 5 Euclidean distance units, except for six isolates (associated with FPTs defined for LMG 18568, LMG 18573, and LMG 18641) that clustered at 10 Euclidean distance units. FAME-MIS identifications as Flavimonas oryzihabitans were congruent with the phenotypic characteristics determined for the isolates. However, identifications as Pseudomonas aeruginosa, though obtained with high similarity value indices ( 0.8 to 0.9 ), appeared unacceptable because the isolates were nonfluorescent, negative for oxidase, and lacked the typical colony morphology of Pseudomonas aeruginosa. Also, Biolog analysis of those isolates provided unsatisfactory identifications with low similarity indices to Pseudomonas syringae or Pseudomonas corrugata. Nonfluorescent pseudomonads were found in nearly all samples, except samples 1-1 and 3-7. The Pseudomonas populations represented by the FPTs delineated for LMG 18605 and LMG 18616 were found in five and four samples, respectively.

Xanthomonads were found in 9 of the 11 samples and were not pathogenic on rice in our pathogenicity tests. They possessed the three characteristic fatty acids of the genus Xanthomonas (46): 11:0 iso, 11:0 iso $3 \mathrm{OH}$, and 13:0 iso $3 \mathrm{OH}$. The isolates remained unidentified in FAME-MIS, while identifications as X. campestris pv. dieffenbachia or X. campestris pv. strelitzia were obtained in Biolog. Additionally, the fatty acid profiles of TSA cultures grown for $48 \mathrm{~h}$ were compared with the profiles contained in a database of the genus Xanthomonas created by Yang et al. (49), and did not fit into any of the recognized Xanthomonas spp. BOX-PCR fingerprinting differentiated 16 FPTs within this group of nonpathogenic xanthomonads. The generated profiles did not share more than two or three bands of equal mobility and clustered at an overall similarity of less than $60 \%$. They were unique compared with fingerprint profiles generated from 11 Philippine strains of $X$. oryzae and 24 reference LMG strains of other Xanthomonas spp. (data not shown).

An abridged dendrogram obtained by UPGMA analysis of the whole-cell FAME patterns for the gram-positive bacteria is shown in Figure 2. The dendrogram consisted of two distant groupings, one related to Bacillus spp. and the other to coryneform bacteria. Isolates identified as Bacillus spp. were contained in FAME groups P7 to P11, with respective identifications of Bacillus licheniformis, Bacillus subtilis, Bacillus megaterium, Bacillus pumilus, and Bacillus cereus. Eleven Bacillus-like isolates remained ungrouped on the basis of their fatty acid compositions (Table 3). The isolates within FAME group P8 were equally identified in comparison with the commercial TSBA library to Bacillus amyloliquefaciens and Bacillus subtilis, often with a numerical difference of less than 0.1 between the first and second choice similarity index value. Hence, for convenience, this group was named Bacillus subtilis group (sensu stricto).

The coryneform isolates were not always clearly differentiated by FAME-MIS. The generated BOX-PCR fingerprints, though very distinct, often shared few bands in common among isolates identified to different coryneform species. The isolates within FAME group P1 formed two subgroups delineated at seven Euclidean distance units. One subgroup was identified to Clavibacter michiganense subsp. insidiosum, whereas the isolates within the other subgroup showed low similarity indices to the library profile for this species. The isolates within each identified Microbacterium sp. were homogeneous both in FAME and in BOX- 
PCR analysis. For example, five of the six Microbacterium saperdae isolates within FAME group $\mathrm{P} 3$, though isolated from four different samples, produced identical BOX-PCR profiles. The single isolate LMG 18654 was different from the other five isolates both in BOX-PCR and FAME analysis. The Microbacterium liquefaciens and Microbacterium barkeri isolates formed two subgroups delineated at 5 Euclidean distance units within FAME group P5, and produced a single BOX-PCR FPT within each subgroup. Isolates identified as Corynebacterium aquaticum were heterogeneous both in BOX-PCR fingerprints and in fatty acid composition (Table 3).
In addition, FAME and BOX-PCR analyses were done for all 83 bacterial colonies that were picked from soak extracts of two arbitrarily chosen in vitro germinated seed samples 23-7 and 28-9. BOX-PCR fingerprinting differentiated 25 FPTs among the 83 isolates from the two germinated seed samples. Eleven FPTs matched FPTs previously found in the ungerminated crushed seed (in order of occurrence in Table 2: LMG 18631, LMG 18618, LMG 18623, LMG 18630, LMG 18634, LMG 18576, LMG 18584, LMG 18571, LMG 18642, LMG 18591, and LMG 18573). Of the 83 isolates from the germinated seed, 41 were identified to Enterobacteriaceae. BOX-PCR fingerprinting differentiated

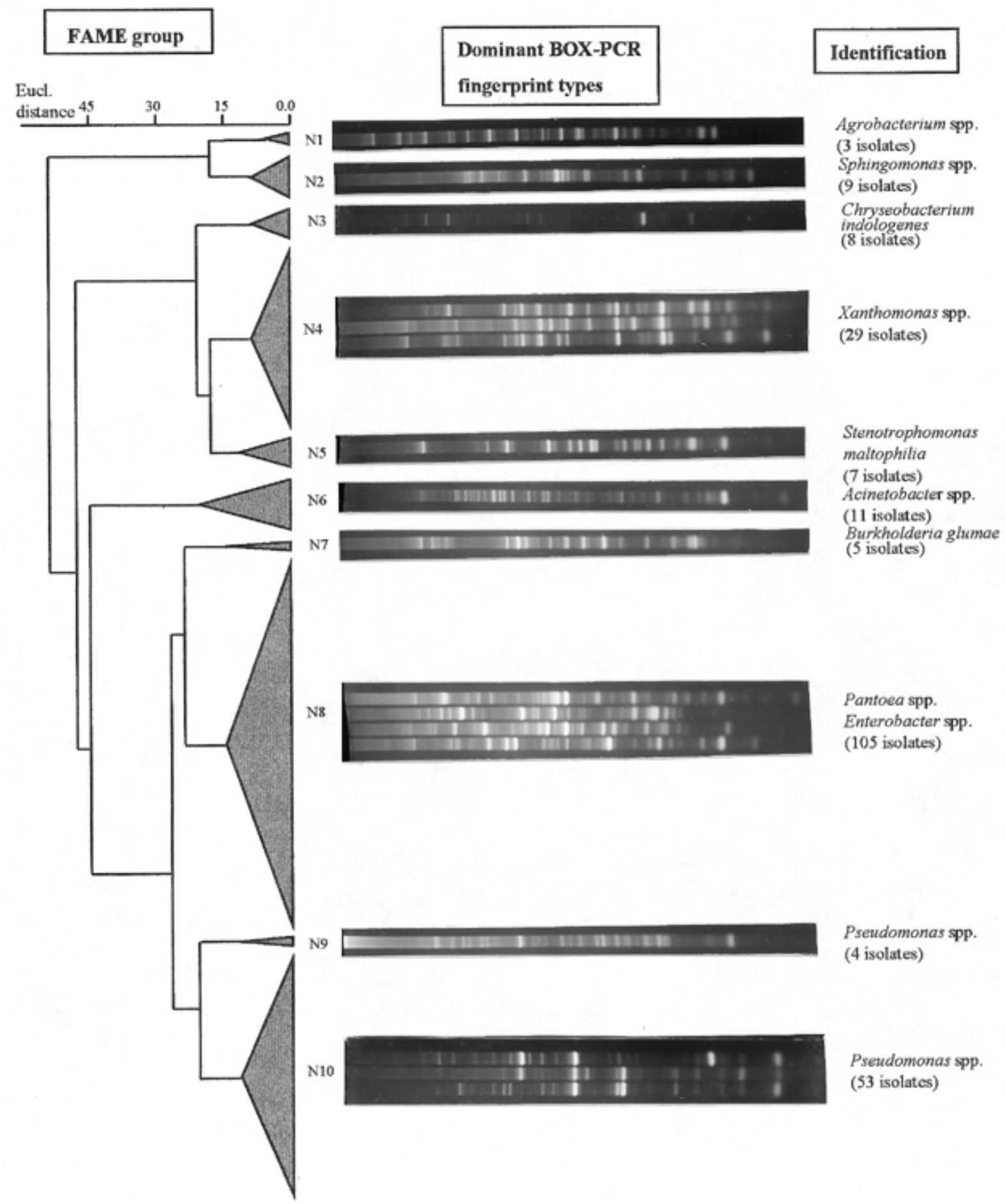

Fig. 1. Abridged dendrogram obtained by unweighted pair group average linkage of Euclidean distance values between fatty acid methyl ester (FAME) profiles of gram-negative bacteria isolated from rice seed. Ungrouped isolates were not included. Dominant polymerase chain reaction (BOX-PCR) fingerprint types delineated among the isolates within each FAME group illustrate the genetic heterogeneity present in each FAME cluster. Identifications were obtained by FAME-MIS, Biolog GN MicroPlates, and API 20E/50CHE systems. 
10 FPTs among these enterobacterial isolates; only 4 matched previously found FPTs in the ungerminated crushed seed. A representative strain was deposited in the LMG culture collection for isolates identified by Biolog as Enterobacter agglomerans biogroup 7 (LMG 18791), biogroup 5 (LMG 18792), biogroup 2B (LMG 18790), and Enterobacter cloacae (LMG 18793). Four FPTs were differentiated among six isolates identified as Sphingomonas paucimobilis. Two FPTs of nonfluorescent pseudomonads that were previously found in ungerminated seed matched the patterns generated from 16 isolates in the germinated seed. A new pseudomonad FPT (represented by deposited isolate LMG 18794) was generated from seven isolates identified as Pseudomonas stutzerii, and revealed a profile nearly identical to the profile from the Pseudomonas stutzerii-type strain LMG 11199 (data not shown). Two FPTs were delineated among fluorescent pseudomonads identified as Pseudomonas putida. Also, two FPTs of nonpathogenic xanthomonads were found in the germinated seed. One FPT was defined for a single isolate identified as Alcaligenes $x y$ losoxydans. Only two FPTs for gram-positive bacteria were found, one from each germinated sample, and both were identified as Paenibacillus polymyxa. A general observation based on the results of the phenotypic tests performed on all isolates from the other nine germinated samples was that gram-positive bacteria were nearly absent in the soak extracts from germinated seed.

Assuming each BOX-PCR FPT is a single population, the number of FPTs in a sample can be used as a measure of the population diversity. The results from the BOX-PCR fingerprinting, although only one-time isolations were done from the samples, suggested that considerable differences in population diversity can be found among samples (Fig. 3).

Pathogenicity tests. Among the 428 isolates from crushed seed, 7 isolates consistently caused symptoms on all 12 plants that were inoculated, and 22 isolates caused variable symptoms on 6 to 11 of inoculated plants. The remaining 399 isolates induced no symptoms, or induced a hypersensitive-like reaction localized at the point of inoculation.

The seven pathogenic isolates were found in six samples and were clearly virulent on rice. Five isolates (represented by deposited strain LMG 18634) had uniform BOX-PCR fingerprints similar to the generated profile from Burkholderia glumae-type strain LMG 2196, and two isolates (represented by deposited strain LMG 18569) had a BOX-PCR profile similar to the type strain of Burkholderia gladioli pv. gladioli LMG 2216 (data not shown). The two groups of isolates also were clearly differentiated on the basis of their fatty acid composition (Table 2). Comparison of their whole-cell protein profiles with the profiles in the Burkholderia database generated by Vandamme et al. (45) positively identified five isolates to Burkholderia glumae and two isolates to Burkholderia gladioli. All seven isolates induced similar symptoms when inoculated by injection into rice plants, except that the Burkholderia gladioli isolates appeared less aggressive. Infection was rapid and characterized by the development of

TABLE 2. Gram-negative bacteria from rice seed ${ }^{\mathrm{a}}$

\begin{tabular}{|c|c|c|c|}
\hline 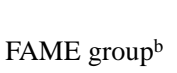 & Identification $^{\mathrm{c}}$ & No. of FPTs (LMG no. $)^{d}$ & $\begin{array}{l}\text { Origin } \\
\text { (no. of isolates) }^{\mathrm{e}}\end{array}$ \\
\hline N 1 & Agrobacterium spp. & 3 FPTs $(18631,18633,18565)$ & 2 seed lots $(3)$ \\
\hline \multirow[t]{2}{*}{ N 2} & Sphingomonas paucimobilis & 4 FPTs $(18624,18625,18618,18575)$ & 4 seed lots $(8)$ \\
\hline & Sphingomonas capsulata & 1 FPT (18601) & 1 seed lot $(1)$ \\
\hline N 3 & Chryseobacterium indologenes & 3 FPTs $(18594,18595,18636)$ & 1 seed lot $(8)$ \\
\hline $\mathrm{N} 4$ & $\begin{array}{l}\text { Xanthomonas campestris pv. dieffenbachia (B), } \\
\text { Xanthomonas campestris pv. strelitzia (B) }\end{array}$ & $\begin{array}{l}16 \text { FPTs }(18567,18578,18582,18589,18610,18612,18613,18614, \\
\quad 18617,18622,18623,18630,18635,18637,18643,18645)\end{array}$ & 9 seed lots $(29)$ \\
\hline N 5 & Stenotrophomonas maltophilia & 2 FPTs $(18581,18646)$ & 2 seed lots $(7)$ \\
\hline \multirow[t]{2}{*}{ N 6} & Acinetobacter baumannii & 3 FPTs $(18599,18609,18644)$ & 6 seed lots (9) \\
\hline & Acinetobacter calcoaceticus & 2 FPTs $(18592,18598)$ & 2 seed lots $(2)$ \\
\hline $\mathrm{N} 7$ & Burkholderia glumae (SDS) & 1 FPT (18634) & 4 seed lots $(5)$ \\
\hline \multirow[t]{7}{*}{ N 8} & Enterobacter cloacae $(\mathrm{B})$ & 3 FPTs $(18576,18607,18626)$ & 5 seed lots $(9)$ \\
\hline & Enterobacter sakazakii (B) & 2 FPTs $(18584,18640)$ & 4 seed lots $(20)$ \\
\hline & Kluyvera ascorbata & 2 FPTs $(18588,18627)$ & 2 seed lots (3) \\
\hline & Pantoea agglomerans & 4 FPTs $(18576,18579,18597,18621)$ & 3 seed lots (12) \\
\hline & Pantoea ananatis & 1 FPT (18639) & 1 seed lot $(1)$ \\
\hline & Pantoea spp. (API) & 5 FPTs $(18570,18571,18572,18638,18642)$ & 8 seed lots $(38)$ \\
\hline & Salmonella choleraesuis & 5 FPTs $(18580,18587,18608,18609,18620)$ & 7 seed lots $(22)$ \\
\hline N 9 & Pseudomonas spp. (B) & 2 FPTs $(18586,18611)$ & 2 seed lots (4) \\
\hline \multirow[t]{3}{*}{ N 10} & Flavimonas oryzihabitans & 4 FPTs $(18583,18596,18605,18628)$ & 6 seed lots $(15)$ \\
\hline & Pseudomonas aeruginosa & 7 FPTs $(18574,18585,18591,18600,18616,18619,18629)$ & 6 seed lots $(32)$ \\
\hline & Pseudomonas spp. (B) & 3 FPTs $(18568,18573,18641)$ & 4 seed lots $(6)$ \\
\hline \multirow[t]{7}{*}{ Ungrouped } & Burkholderia gladioli (SDS) & 1 FPT (18569) & 2 seed lots $(2)$ \\
\hline & Burkholderia multivorans (SDS) & 1 FPT (18606) & 1 seed lot (1) \\
\hline & Methylobacterium rhodesianum & 1 FPT (18593) & 1 seed lot (1) \\
\hline & Pectobacterium carotovorum (API) & 1 FPT (18632) & 1 seed lot (1) \\
\hline & Pseudomonas putida & 2 FPTs $(18566,18615)$ & 2 seed lots $(2)$ \\
\hline & Pseudomonas spp. & 1 FPT (18604) & 1 seed lot (1) \\
\hline & Sphingomonas paucimobilis (B) & 2 FPTs $(18590,18602)$ & 2 seed lots $(2)$ \\
\hline
\end{tabular}

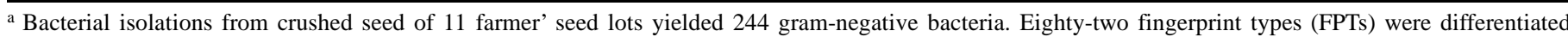
among these isolates on the basis of polymerase chain reaction (BOX-PCR) fingerprinting of genomic DNA. The FPTs were arranged according to the groups from the cluster analysis of fatty acid profiles of the isolates.

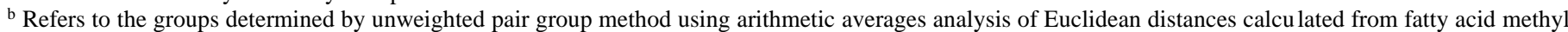
ester (FAME) data of the 244 gram-negative rice seed isolates. Ungrouped: isolates with fatty acid profiles that remained unclu stered at a level of 12 Euclidean distance units.

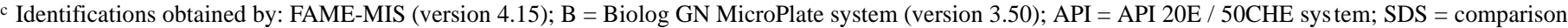
of sodium dodecyl sulfate-polyacrylamide gel electrophoresis whole-cell protein profiles with the predetermined Burkholderia library from Vandamme et al. (45).

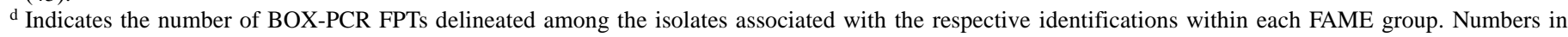
parentheses refer to the accession number of deposited representative isolates for each FPT in the culture collection of the Laboratorium Microbiologie Gent (LMG), Gent, Belgium.

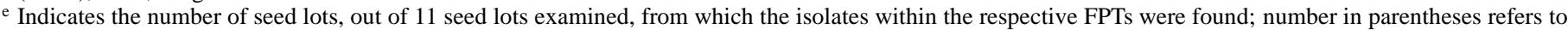
the actual number of isolates found within the respective FPTs. 
brown necrotic lesions on the sheath plus apparent chlorosis of the second and third leaves within 3 days after inoculation. The leaves gradually wilted and brown rot developed on the sheath; the plant usually collapsed. Infection with Burkholderia glumae isolates always led to death of the entire plant.

Twenty-two isolates caused symptoms of sheath necrosis to a variable extent on only 50 to $90 \%$ of inoculated plants and were considered pathogens with low disease potential. Seven isolates were identified as Bacillus pumilus by FAME-MIS, two as Paenibacillus spp., nine were nonfluorescent pseudomonads, and four were Pantoea spp. They were delineated by 10 BOX-PCR FPTs, which, however, often also comprised isolates without disease potential. The reaction of the Bacillus pumilus and Paenibacillus isolates on the inoculated plants was constant among the three inoculation experiments. They induced water-soaked blotches and streaks on the sheath and along the margins of the third leaf; the second leaf often appeared curled and grayish-green. After 10 days, the sheath showed brown necrotic zones and affected leaves were wilted. The reactions elicited by the Pantoea spp. and pseudomonad isolates on inoculated plants were variable in severity of caused symptoms between the first and the following two inoculation experiments, making it difficult to determine if they were virulent or not. Clearly, further work is needed to establish their real pathogenic potential.

Antifungal activity. Screening of all 428 rice bacterial isolates yielded 17 bacteria that exhibited in vitro antifungal activity against one of the four tested fungal rice pathogens. $R$. solani was the most sensitive fungal pathogen and was inhibited by 14 isolates; Pyricularia grisea was inhibited by three isolates (Table 4). None of the isolates inhibited Fusarium moniliforme or Sarocladium oryzae. These 17 antagonists, found in 6 of the 11 samples, were associated with 13 BOX-PCR FPTs, and 9 of these FPTs included both producers and nonproducers of antifungal compounds. Two of the five FPTs associated with eight isolates identified as Bacillus subtilis showed different inhibition spectra.

\section{DISCUSSION}

Studies on bacterial populations associated with the rice plant have traditionally focused on the organisms of obvious interest

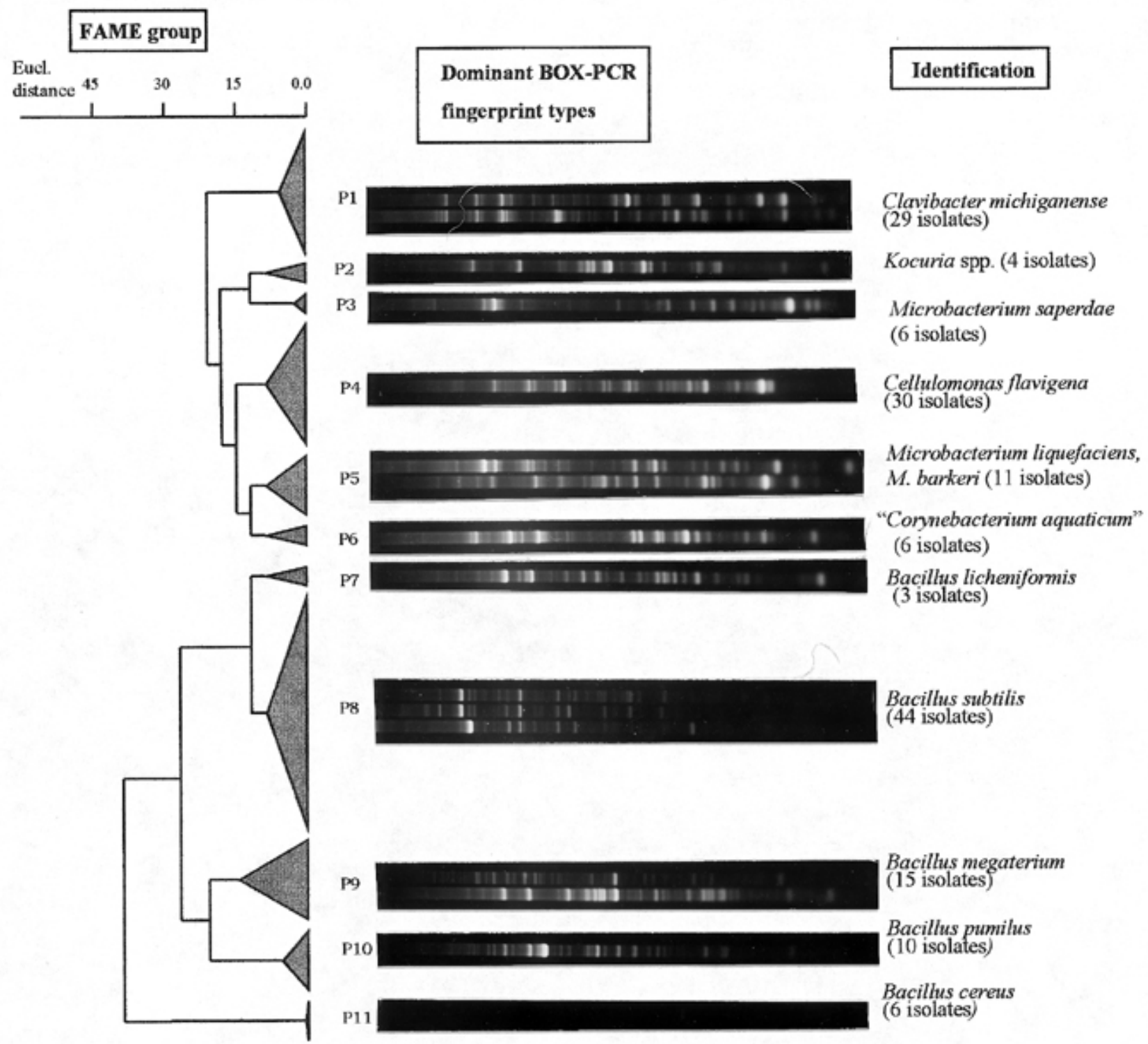

Fig. 2. Abridged dendrogram obtained by unweighted pair group average linkage of Euclidean distance values between fatty acid methyl ester (FAME) profiles of gram positive bacteria isolated from rice seed. Ungrouped isolates were not included. Dominant polymerase chain reaction (BOX-PCR) fingerprint types delineated among the isolates within each FAME group illustrate the genetic heterogeneity present in each FAME cluster. Identifications were obtained by FAME-MIS (version 4.15). 
(i.e., pathogens or biological control agents) and have commonly neglected the other large fraction of saprophytic, opportunistic, and symbiotic bacteria. The aim of this study was to provide more insight into the qualitative composition of bacterial communities associated with rice seed. The seed was of particular interest because of its importance as planting material and its potential as vehicle for transmission of beneficial or deleterious bacteria. Single bacterial isolates were characterized by BOX-PCR fingerprint typing of genomic DNA. This technique allowed the comparison of fingerprints of individual isolates between samples. Several studies have reported the usefulness of the rep-PCR technique to fingerprint a large variety of bacteria, and its ability to differentiate bacteria at the species, pathovar, or strain level $(19,20,38,47)$. The results of the BOX-PCR genomic fingerprinting revealed a large variety of bacteria with unique fingerprints and groups of bacteria with nearly identical fingerprints that were isolated from different samples. In this study, very few fingerprints of identified isolates matched the profiles of corresponding LMG reference strains. Previous studies using DNA fingerprinting have demonstrated considerable variability within bacterial taxonomic groups $(18-20,47)$. Also, the preliminary BOX-PCR analysis in this study of selected LMG reference strains indicated that the degree of variability found within a species varied among species. The revealed diversity in BOX-PCR fingerprints complicated the interpretation of relatedness between the large number of seed isolates. Therefore, phenotypic characterization and whole-cell fatty acid analysis was useful to achieve relevant phenotypic groupings in order to facilitate the interpretation of the obtained variability in BOX-PCR profiles. The results of this study revealed a high diversity of seed-associated bacteria despite the known limitations of traditional cultivation techniques $(1,42)$. In addition, the pure culture approach allowed for further testing and characterization of pathogenic and antagonistic isolates.

On the basis of FAME and BOX-PCR analysis, Enterobacteriaceae were the most diverse group of isolates among the gramnegative bacteria found in rice seed. The enterobacterial populations as determined by distinct BOX-PCR fingerprints may reflect a differentiation at the subspecies or even strain level (47). Pantoea populations, followed by Enterobacter populations related to Enterobacter cloacae and Enterobacter sakazakii, dominated the group of Enterobacteriaceae. Identifications at the species level, however, remained doubtful for many isolates. In previous studies, the extreme heterogeneity of the species Enterobacter agglomerans was shown and has been amended into several Pantoea spp. $(4,9,23)$. Therefore, obtained identifications of Enterobacter agglomerans from the taxonomically older entries in the API library were for convenience given as Pantoea spp. The diversity of enterobacterial species associated with rice seed has been largely overlooked in the past, because only Erwinia herbicola (subjective synonym of Pantoea agglomerans) is reported to be commonly isolated from infected and healthy rice seed $(3,25$, 29,50). In this study, two frequently found enterobacterial FPTs

TABLE 3. Gram-positive bacteria from rice seed ${ }^{\mathrm{a}}$

\begin{tabular}{|c|c|c|c|}
\hline 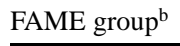 & Identification $^{\mathrm{c}}$ & No. of FPTs (LMG no.) ${ }^{\mathrm{d}}$ & Origin (no. of isolates) ${ }^{\mathrm{e}}$ \\
\hline P 1 & Clavibacter michiganense & 6 FPTs $(18656,18657,18661,18695,18697,18701)$ & 9 seed lots (29) \\
\hline P 2 & Kocuria kristinae & 3 FPTs $(18651,18680,18681)$ & 3 seed lots (4) \\
\hline P 3 & Microbacterium saperdae & 2 FPTs $(18654,18664)$ & 5 seed lots $(6)$ \\
\hline \multirow[t]{3}{*}{ P 5} & Microbacterium barkeri & 1 FPT (18662) & 2 seed lots ( 3 ) \\
\hline & Microbacterium liquefaciens & 1 FPT (18700) & 2 seed lots (7) \\
\hline & "Corynebacterium aquaticum" & 1 FPT (18699) & 1 seed lot (1) \\
\hline P 6 & "Corynebacterium aquaticum" & 1 FPT (18713) & 2 seed lots (2) \\
\hline P 8 & Bacillus subtilis-group (sensu stricto) & $\begin{array}{l}11 \text { FPTs }(18652,18671,18679,18684,18691,18694, \\
18703,18704,18707,18709,18715)\end{array}$ & 8 seed lots (44) \\
\hline P 9 & Bacillus megaterium & 7 FPTs $(18670,18686,18687,18688,18705,18710,18714)$ & 6 seed lots (15) \\
\hline P 10 & Bacillus pumilus & 2 FPTs $(18658,18676)$ & 6 seed lots $(10)$ \\
\hline P 11 & Bacillus cereus & 3 FPTs $(18653,18675,18698)$ & 4 seed lots $(6)$ \\
\hline \multirow[t]{10}{*}{ Ungrouped } & Arthrobacter atrocyaneus & 1 FPT (18689) & 1 seed lot (1) \\
\hline & "Bacillus filicolonicus" & 1 FPT (18692) & 1 seed lot (1) \\
\hline & "Corynebacterium aquaticum" & 2 FPTs $(18702,18708)$ & 2 seed lots (2) \\
\hline & Curtobacterium spp. (B) & 1 FPT (18672) & 1 seed lot (1) \\
\hline & Exiguobacterium acetylicum & 1 FPT (18674) & 1 seed lot (1) \\
\hline & Microbacterium arborescens & 1 FPT (18693) & 1 seed lot (1) \\
\hline & Paenibacillus macerans & 1 FPT (18690) & 1 seed lot (1) \\
\hline & Paenibacillus polymyxa & 1 FPT (18678) & 1 seed lot (1) \\
\hline & Paenibacillus spp. & 2 FPTs $(18660,18666)$ & 2 seed lots (2) \\
\hline & Staphylococcus saprophyticus & 1 FPT (18673) & 1 seed lot (2) \\
\hline
\end{tabular}

a Bacterial isolations from crushed seed of 11 farmers' seed lots yielded 184 gram positive bacteria. Sixty-nine fingerprint types (FPTs) were differentiated among these isolates on the basis of polymerase chain reaction (BOX-PCR) fingerprinting of genomic DNA. The FPTs were arranged according to the groups from the cluster analysis of fatty acid profiles of the isolates.

${ }^{\mathrm{b}}$ Refers to the groups determined by unweighted pair group method using arithmetic averages analysis of Euclidean distances calcu lated from fatty acid methyl ester (FAME) data of the 184 gram-positive rice seed isolates. Ungrouped: isolates with fatty acid profiles that remained unclu stered at a level of 12 Euclidean distance units.

${ }^{\mathrm{c}}$ Identifications obtained by: FAME-MIS (version 4.15); B = Biolog GP MicroPlate system (Microlog version 3.50); names in quotation marks are not validated.

${ }^{\mathrm{d}}$ Indicates the number of BOX-PCR FPTs delineated among the isolates associated with the respective identifications within each FAME group. Numbers in parentheses refer to the accession number of deposited representative isolates for each FPT in the culture collection of the Laboratorium Microbiologie Gent (LMG), Gent, Belgium.

${ }^{\mathrm{e}}$ Indicates the number of seed lots, out of 11 seed lots examined, from which the isolates within the respective FPTs were found. The number in parentheses refers to the actual number of isolates found within the respective FPTs. 
(represented by LMG 18570 and LMG 18571) had highly similar patterns to the pattern generated for the Pantoea stewartii subsp. stewartii-type strain LMG 2715 (previously Erwinia stewartii).

Pseudomonads can commonly be isolated from healthy and discolored rice seed and are primarily considered saprophytes, although some are biocontrol agents $(24,33,34)$ or rice pathogens $(2,16,26,29)$. Several have been associated with the seed discoloration and leaf sheath rot syndrome of rice $(8,50)$. In this study, mainly nonfluorescent pseudomonads were found that were homogeneous in fatty acid composition but clearly heterogeneous on the basis of BOX-PCR analysis. Identification of these pseudomonads by FAME-MIS and Biolog often gave inaccurate results; only $26 \%$ of isolates were correctly identified with these methods. FAME-MIS identifications as Flavimonas oryzihabitans were acceptable, but identifications as Pseudomonas aeruginosa were suspicious.

Since the last decade, the occurrence of nonpathogenic xanthomonads occasionally has been reported from rice seed as well as from other crops $(13,25,46)$. The present results clearly indicate that nonpathogenic xanthomonads are commonly associated with rice seed. These isolates formed a homogeneous group on the basis of fatty acid composition but revealed a high diversity in BOX-PCR fingerprints. They did not fit into any recognized Xanthomonas sp. in the fatty acid database created by Yang et al. (49) and, thus, seem to occupy a unique position within the genus Xanthomonas. The only known Xanthomonas sp. on rice is X. oryzae, comprising the two pathovars oryzae and oryzicola, causing bacterial leaf blight and bacterial leaf streak on rice, respec- tively (29). These nonpathogenic xanthomonads can be confused with $X$. oryzae based on similar colony appearance (25) and, therefore, may be incorrectly identified as $X$. oryzae. However, they certainly did not belong to $X$. oryzae both in FAME and BOX-PCR analyses.

An unexpected finding was the large diversity of bacilli and coryneform bacteria that can be found associated with rice seed. These populations have hardly been explored in the past; hence, little is known about their presence and significance as a component of the rice seed microflora. To our knowledge, this is the first report of coryneform bacteria in rice seed. These populations should not be neglected, because they may represent not only an untapped resource of beneficial properties but also a source of unknown disease potential. For instance, some isolates exhibited antifungal activity and others were able to induce symptoms of sheath necrosis on rice.

Two percent of the isolates were seedborne pathogens identified as Burkholderia spp. and were found in $55 \%$ of the samples. Burkholderia glumae is recognized as an important rice pathogen causing both seed rot (10) and seedling rot (43). On the other hand, reports on Burkholderia gladioli as a rice pathogen are limited and come only from Japan (44). Burkholderia plantarii, another Burkholderia sp. known as a rice pathogen causing seedling blight (2), was not found in the seed samples. Furthermore, an illdefined group comprising $5 \%$ of the total number of isolates caused symptoms of sheath necrosis to a variable extent on 50 to $90 \%$ of inoculated plants. These isolates were identified as Bacillus pumilus, Paenibacillus spp., Pseudomonas spp., and Pantoea

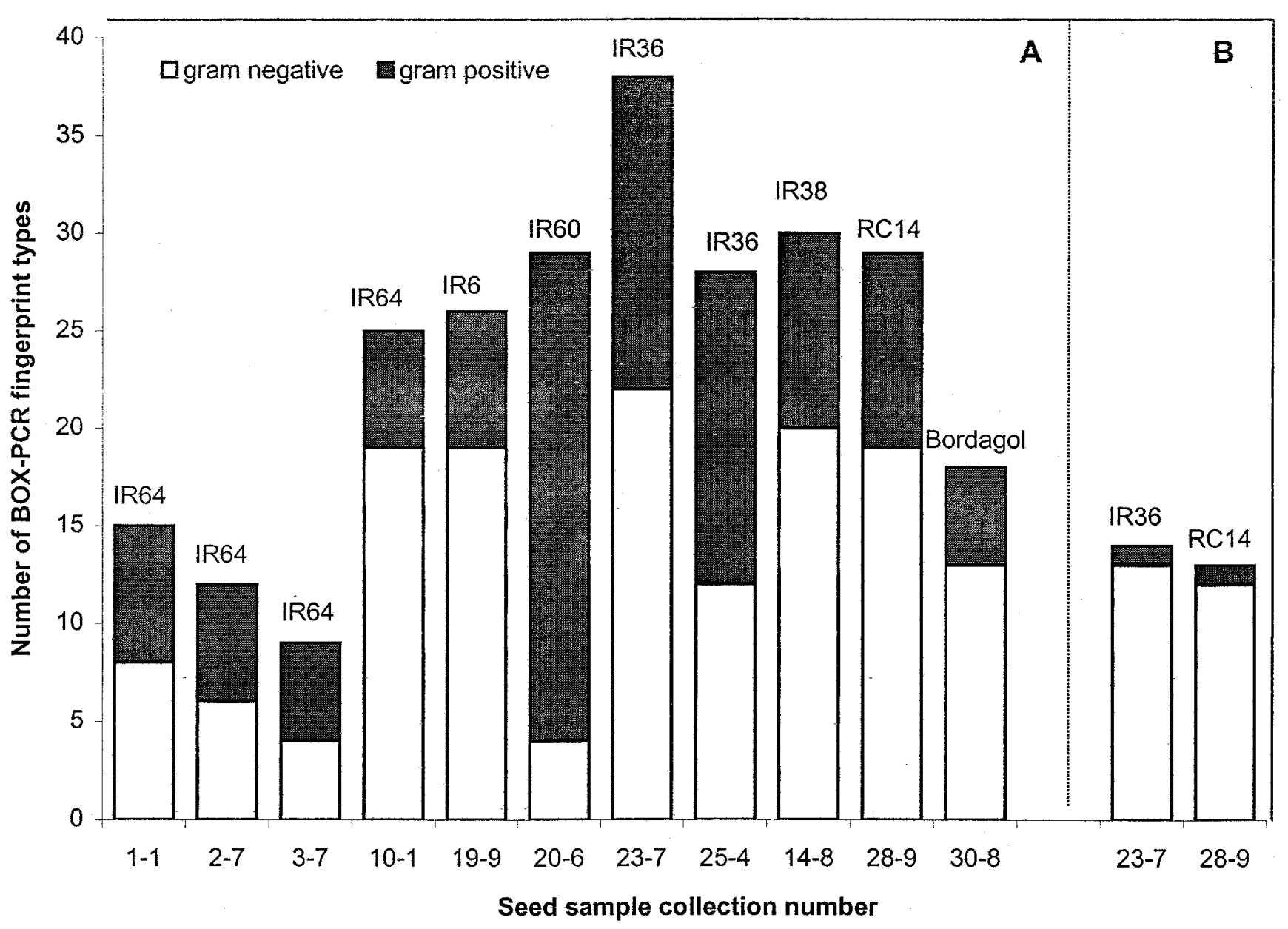

Fig. 3. Bacterial population diversity found in rice seed samples on the basis of polymerase chain reaction (BOX-PCR) fingerprint types delineated among the number of colonies isolated from each sample collected during the 1995 wet-season harvest in Iloilo, Philippines. Isolations were done once from each sample. The respective rice cultivar is indicated on top of each bar. A, Number of bacterial populations found in crushed 10-g rice seed samples; and $\mathbf{B}$, number of bacterial populations found in two soaked 10 -g rice seed samples after in vitro germination. 
spp. They were considered pathogens with low disease potential and were different from true pathogens on the basis of lower aggressiveness and inconsistency in producing symptoms. The choice of inoculation method may have been inappropriate for assessing the true virulence of these isolates; however, the majority of isolates did not induce symptoms on rice plants upon inoculation. The disease potential on rice of Pantoea agglomerans strains (3), synanamorph Erwinia herbicola (4,9), and strains related to saprophytic Pseudomonas spp. $(8,50)$, has previously been reported. Usually regarded as saprophytes, these bacteria have not been given much attention in the past. However, such isolates were regularly recovered from rice seed in subsequent isolations, and further work to establish their disease potential is in progress.

In the present study, $4 \%$ of the bacteria isolated showed in vitro antifungal activity. The majority (82\%) inhibited the mycelial growth of $R$. solani, whereas the other isolates inhibited Pyricularia grisea. Nearly half $(47 \%)$ of the antagonists were identified as Bacillus subtilis; the other isolates with antifungal activity belonged to various taxa. Strains of Bacillus subtilis (24,33), Enterobacter cloacae (28), and Pantoea agglomerans (synanamorph Erwinia herbicola) $(28,33)$ have been used as biological control agents against rice fungal diseases. The potential use of Stenotrophomonas maltophilia as a biological control agent has been explored $(5,51)$. However, in vitro inhibition of mycelial growth does not guarantee that these strains will be effective biocontrol agents (24), and further work to establish their potential in vivo is needed.

To assess the impact of seed germination on the composition of bacterial communities, BOX-PCR and FAME analyses were performed on isolates obtained from two arbitrarily chosen germinated seed samples. It is assumed that the large majority of bacteria are localized in and under the rice hull and, therefore, can be released from the seed by soaking. Results from recent experiments have shown that isolations by seed soaking give comparable results and, often, a larger number of colony morphotypes compared with isolations by seed crushing (B. Cottyn, unpub-

TABLE 4. Rice seed isolates with in vitro antifungal activity

\begin{tabular}{|c|c|c|c|}
\hline \multirow[b]{2}{*}{ Identification $^{\mathrm{a}}$} & \multirow[b]{2}{*}{ Collection no. ${ }^{\mathrm{b}}$} & \multicolumn{2}{|c|}{ Inhibition zone $(\mathrm{mm})^{\mathrm{c}}$} \\
\hline & & R. solani & P. grisea \\
\hline \multirow[t]{3}{*}{ Pantoea spp. (API) } & G2 & 11 & 0 \\
\hline & G4 & 11.7 & 0 \\
\hline & G193 & 8 & 0 \\
\hline Enterobacter cloacae (B) & G5 (LMG 18607) & 7.5 & 0 \\
\hline \multicolumn{4}{|l|}{ Stenotrophomonas } \\
\hline maltophilia & G266 (LMG 18581) & 7.7 & 0 \\
\hline Xanthomonas spp. (B) & G314 (LMG 18637) & 10.3 & 0 \\
\hline Acinetobacter baumannii & G6 & 7.5 & 0 \\
\hline Paenibacillus macerans & G429 (LMG 18690) & 0 & 33 \\
\hline Cellulomonas flavigena & G7 (LMG 18647) & 6.7 & 0 \\
\hline \multirow[t]{8}{*}{ Bacillus subtilis } & G229(LMG 18671) & 9 & 0 \\
\hline & G460 & 10.3 & 0 \\
\hline & G396 & 0 & 26 \\
\hline & G425 (LMG 18707) & 0 & 21.5 \\
\hline & G364 & 8.3 & 0 \\
\hline & G329 & 12.0 & 0 \\
\hline & G412 & 8.3 & 0 \\
\hline & G452 (LMG 18715) & 9.5 & 0 \\
\hline
\end{tabular}

$\bar{a}$ Identifications obtained by fatty acid methyl ester (FAME)-MIS (version 4.15); B = Biolog GN MicroPlate system (Microlog version 3.50); API = API 20E / 50CHE system.

${ }^{\mathrm{b}}$ Accession numbers refer to the collection of the Entomology and Plant Pathology Division at the International Rice Research Institute, Los Baños, Philippines. Numbers in parentheses refer to the accession numbers of duplicate cultures deposited in the culture collection of the Laboratorium Microbiologie Gent (LMG), Gent, Belgium.

${ }^{c}$ Values represent the mean diameter of mycelial growth inhibition zones on Rhizoctonia solani and Pyricularia grisea for three replicates measured after 3 days of incubation at $28^{\circ} \mathrm{C}$. Inhibition was determined on pigment production medium. lished data). FAME analysis of the isolates from the two germinated samples suggested that the main phenotypic groups of gramnegative bacteria found in ungerminated seed were also present after germination. The overall diversity of populations as reflected by the number of BOX-PCR FPTs was lower. The most apparent result was the near absence of gram-positive bacteria. Only isolates identified as Paenibacillus polymyxa were found and, interestingly, this was also the single gram-positive species isolated from rice seedlings in the study by Mukhopadhyay et al. (28). Further, a qualitative shift in the composition of enterobacterial populations was found. Populations not isolated before germination dominated the populations that persisted after germination. It is suggested that exudates from germinating seed create a different environment that can inhibit or induce the proliferation of certain bacteria (31). Second, the increase in one population of the community can likewise affect other populations.

In conclusion, BOX-PCR analysis of a collection of rice seed isolates revealed a high heterogeneity within the bacterial communities associated with rice seed. However, the function of this genetic diversity among populations of bacteria in relation to environmental variables, including farmers' cultural practices, is not clear. Further research that elucidates the mechanisms eliciting this genetic diversity is needed. An understanding of the ecology of natural microbial communities should lead to a more efficient deployment of bacterial populations for disease management.

\section{ACKNOWLEDGMENTS}

This work was supported by a grant from the Directorate-General for International Collaboration (DGIC, Belgium). We thank P. Vandamme (RUG, Gent, Belgium) for his valuable advice and support in the characterization of the Burkholderia isolates.

\section{LITERATURE CITED}

1. Amann, R., Ludwig, W., and Schleifer, K.-H. 1995. Phylogenetic identification and in situ detection of individual microbial cells without cultivation. Microbiol. Rev. 59:143-169.

2. Azegami, K., Nishiyama, K., Watanabe, Y., Kadota, I., Ohuchi, A., and Fukazawa, C. 1987. Pseudomonas plantarii sp. nov., the causal agent of rice seedling blight. Int. J. Syst. Bacteriol. 37:144-152.

3. Azegami, K., Ozaki, K., Matsuda, A., and Ohata, K. 1983. Bacterial palea browning, a new disease of rice caused by Erwinia herbicola. Bull. Natl. Inst. Agric. Sci. Ser. C (Jpn.) 37:1-12.

4. Beji, A., Mergaert, J., Gavini, F., Izard, D., Kersters, K., Leclerc, H., and De Ley, J. 1988. Subjective synonymy of Erwinia herbicola, Erwinia milletiae, and Enterobacter agglomerans and redefinition of the taxon by genotypic and phenotypic data. Int. J. Syst. Bacteriol. 38:77-88.

5. Berg, G., Marten, P., and Balling, G. 1996. Stenotrophomonas maltophilia in the rhizosphere of oil-seed rape-occurrence, characterization, and interaction with phytopathogenic fungi. Microbiol. Res. 151:19-27.

6. Blakeman, J. P., and Fokkema, N. J. 1982. Potential for biological control of plant disease on the phylloplane. Annu. Rev. Phytopathol. 20:167-192.

7. Cook, R. J. 1993. Making greater use of introduced microorganisms for biological control of plant pathogens. Annu. Rev. Phytopathol. 31:53-80.

8. Cottyn, B., Van Outryve, M. F., Cerez, M. T., De Cleene, M., Swings, J., and Mew, T. W. 1996. Bacterial diseases of rice. II. Characterization of pathogenic bacteria associated with sheath rot complex and grain discoloration of rice in the Philippines. Plant Dis. 80:438-445.

9. Gavini, F., Mergaert, J., Beji, A., Mielcarek, C., Izard, D., Kersters, K., and De Ley, J. 1989. Transfer of Enterobacter agglomerans (Beijerinck 1888) Ewing and Fife 1972 to Pantoea gen. nov. as Pantoea agglomerans comb. nov. and description of Pantoea dispersa sp. nov. Int. J. Syst. Bacteriol. 39:337-345.

10. Goto, K., and Ohata, K. 1956. New bacterial diseases of rice (brown stripe and grain rot). Ann. Phytopathol. Soc. Jpn. 21:46-47.

11. Grimont, P. A. D., Vancanneyt, M., Lefevre, M., Vandemeulebroecke, K., Vauterin, L., Brosch, R., Kersters, K., and Grimont, F. 1996. Ability of Biolog and Biotype-100 Systems to reveal the taxonomic diversity of the Pseudomonads. Syst. Appl. Microbiol. 19:510-527.

12. Jones, J. B., Chase, A. R., and Harris, G. K. 1993. Evaluation of the Biolog GN MicroPlate System for identification of some plant-pathogenic bacteria. Plant Dis. 77:553-558. 
13. Jones, R. K., Barnes, L. W., Gonzales, C. F., Leach, J. E., Alvarez, A. M., and Benedict, A. A. 1989. Identification of low virulence strains of Xanthomonas campestris pv. oryzae from rice in the United States. Phytopathology 79:984-990.

14. King, E. O., Ward, M., and Raney, D. E. 1954. Two simple media for the demonstration of pyocyanin and fluorescein. J. Lab. Clin. Med. 44:301-307.

15. Kogan, S., Doherty, M., and Gitschier, J. 1987. An improved method for prenatal diagnosis of genetic diseases by analysis of amplified DNA sequences. New Engl. J. Med. 317:985-990.

16. Kuwata, H. 1985. Pseudomonas syringae pv. oryzae pv. nov., causal agent of bacterial halo blight of rice. Ann. Phytopathol. Soc. Jpn. 51:212-218.

17. Lelliot, R. A., and Stead, D. E. 1987. Methods for the Diagnosis of Bacterial Diseases of Plants. Blackwell Scientific Publications, Oxford.

18. Louws, F. J., Bell, J., Medina-Mora, C. M., Smart, C. D., Opgenorth, D., Ishimaru, C. A., Hausbeck, M. K., de Bruijn, F. J., and Fulbright, D. W. 1998. rep-PCR-mediated genomic fingerprinting: A rapid and effective method to identify Clavibacter michiganensis. Phytopathology 88:862868 .

19. Louws, F. J., Fulbright, D. W., Stephens, C. T., and de Bruijn, F. J. 1994. Specific genomic fingerprints of phytopathogenic Xanthomonas and Pseudomonas pathovars and strains generated with repetitive sequences and PCR. Appl. Environ. Microbiol. 60:2286-2295.

20. Louws, F. J., Fulbright, D. W., Stephens, C. T., and de Bruijn, F. J. 1995. Differentiation of genomic structure by rep-PCR fingerprinting to rapidly classify Xanthomonas campestris pv. vesicatoria. Phytopathology 85:528-536.

21. Lupski, J. R., and Weinstock, G. M. 1992. Short, interspersed repetitive DNA sequences in prokaryotic genomes. J. Bacteriol. 174:4525-4529.

22. Martin, B., Humbert, O., Camara, M., Guenzi, E., Walker, J., Mitchell, T., Andrew, P., Prudhome, M., Alloing, G., Hakenbeck, R., Morrison, D. A., Boulnois, G. J., and Claverys, J.-P. 1992. A highly conserved repeated DNA element located in the chromosome of Streptococcus pneumoniae. Nucleic Acids Res. 20:3479-3483.

23. Mergaert, J., Verdonck, L., and Kersters, K. 1993. Transfer of Erwinia ananas (synonym, Erwinia uredovora) and Erwinia stewartii to the genus Pantoea emend. as Pantoea ananas (Serrano 1928) comb. nov. and Pantoea stewartii (Smith 1898) comb. nov., respectively, and description of Pantoea stewartii subsp. indologenes subsp. nov. Int. J. Syst. Bacteriol. 43:162-173.

24. Mew, T. W., and Rosales, A. M. 1986. Bacterization of rice plants for control of sheath blight caused by Rhizoctonia solani. Phytopathology 76:1260-1264.

25. Ming, D., Ye, H., Schaad, N. W., and Roth, D. A. 1991. Selective recovery of Xanthomonas spp. from rice seed. Phytopathology 81:1358-1363.

26. Miyajima, K., Tanii, A., and Akita, T. 1983. Pseudomonas fuscovaginae sp. nov., nom. rev. Int. J. Syst. Bacteriol. 33:656-657.

27. Moss, C. W., Samuals, S. B., and Weaver, R. E. 1972. Cellular fatty acid composition of selected Pseudomonas species. Appl. Microbiol. 24: 596-598.

28. Mukhopadhyay, K., Garrison, N. K., Hinton, D. M., Bacon, C. W., Khush, G. S., Peck, H. D., and Datta, N. 1996. Identification and characterization of bacterial endophytes of rice. Mycopathologia 134:151-159.

29. Ou, S. H. 1985. Rice Diseases. 2nd ed. Commonw. Mycol. Inst., Kew, Surrey.

30. Oyaizu-Masuchi, Y., and Komagata, K. 1988. Isolation of free-living nitrogen-fixing bacteria from the rhizosphere of rice. J. Gen. Appl. Microbiol. 34:127-164.

31. Pistole, T. G. 1981. Interactions of bacteria and fungi with lectins and lectin-like substances. Annu. Rev. Microbiol. 35:85-112.

32. Pot, B., Vandamme, P., and Kersters, K. 1994. Analysis of electrophoretic whole-organism protein fingerprinting. Pages 493-521 in: Modern Microbial Methods. Chemical Methods in Bacterial Systematics. M. Goodfellow and A. G. O'Donnell, eds. John Wiley \& Sons, Chichester,
U.K.

33. Rosales, A. M., Vantomme, R., Swings, J., De Ley, J., and Mew, T. W. 1993. Identification of some bacteria from paddy antagonistic to several rice fungal pathogens. J. Phytopathol. (Berlin) 138:189-208.

34. Sakthivel, N., and Gnanamanickam, S. S. 1987. Evaluation of Pseudomonas fluorescens for suppression of sheath rot disease and for enhancement of grain yields in rice (Oryza sativa L.). Appl. Environ. Microbiol. 53:2056-2059.

35. Sambrook, J., Fritsch, E. F., and Maniatis, T. 1989. Molecular Cloning: A Laboratory Manual. 2nd ed. Cold Spring Harbor Laboratory, Cold Spring Harbor, NY.

36. Sasser, M., and Wichman, M. D. 1991. Identification of microorganisms through use of gas chromatography and high-performance liquid chromatography. Pages 111-118 in: Manual Clinical Microbiology, 5th ed. W. J. Hausler Jr., K. L. Hermann, H. D. Isenberg, and H. J. Shadomy, eds. American Society for Microbiology, Washington, D.C.

37. Schaad, N. W. (ed.) 1988. Laboratory Guide for Identification of Plant Pathogenic Bacteria. 2nd ed. The American Phytopathological Society, St. Paul, MN.

38. Schneider, M., and de Bruijn, F. J. 1996. Rep-PCR mediated genomic fingerprinting of rhizobia and computer-assisted phylogenetic pattern analysis. World J. Microbiol. Biotechnol. 12:163-174.

39. Shakya, D. D., and Chung, H. S. 1983. Detection of Pseudomonas avenae in rice seed. Seed Sci. Technol. 11:583-587.

40. Stead, D. E. 1992. Grouping of plant-pathogenic and some other Pseudomonas spp. by using cellular fatty acid profiles. Int. J. Syst. Bacteriol. 42:281-295.

41. Stoltzfus, J. R., So, R., Malarvizhi, P. P., Ladha, J. K., and de Bruijn, F. J. 1997. Isolation of endophytic bacteria from rice and assessment of their potential for supplying rice with biologically fixed nitrogen. Plant Soil 194:25-36.

42. Tiedje, J. M. 1995. Approaches to the comprehensive evaluation of prokaryote diversity of a habitat. Pages 73-87 in: Microbial Diversity and Ecosystem Function. D. Allsopp, R. R. Colwell, and D. L. Hawksworth, eds. CAB International, Wallingford, U.K.

43. Uematsu, T., Yoshimura, D., Nishiyama, K., Ibaraki, T., and Fujii, H 1976. Pathogenic bacterium causing seedling rot of rice. Ann. Phytopathol. Soc. Jpn. 42:464-471.

44. Ura, H., Iiyama, K., Furuya, N., and Matsuyama, N. 1996. Properties of the bacteria isolated from rice plants with leaf-sheath browning and grain rot. Ann. Phytopathol. Soc. Jpn. 62:640.

45. Vandamme, P., Holmes, B., Vancanneyt, M., Coenye, T., Hoste, B., Coopman, R., Revets, H., Lauwers, S., Gillis, M., Kersters, K., and Govan, J. R. W. 1997. Occurrence of multiple genomovars of Burkholderia cepacia in cystic fibrosis patients and proposal of Burkholderia multivorans sp. nov. Int. J. Syst. Bacteriol. 47:1188-1200.

46. Vauterin, L., Yang, P., Alvarez, A., Takikawa, Y., Roth, D. A., Vidaver, A. K., Stall, R. E., Kersters, K., and Swings, J. 1996. Identification of non-pathogenic Xanthomonas strains associated with plants. Syst. Appl. Microbiol. 19:96-105.

47. Versalovic, J., Koeuth, T., and Lupski, J. R. 1991. Distribution of repetitive DNA sequences in eubacteria and application to fingerprinting of bacterial genomes. Nucleic Acids Res. 19:6823-6831.

48. Welch, D. F. 1991. Applications of cellular fatty acid analysis. Clin. Microbiol. Rev. 4:422-438.

49. Yang, P., Vauterin, L., Vancanneyt, M., Swings, J., and Kersters, K. 1993. Application of fatty acid methyl esters for the taxonomic analysis of the genus Xanthomonas. Syst. Appl. Microbiol. 16:47-71.

50. Zeigler, R. S., and Alvarez, E. 1990. Characteristics of Pseudomonas spp. causing grain discoloration and sheath rot of rice, and associated pseudomonad epiphytes. Plant Dis. 74:917-922.

51. Zhang, Z., and Yuen, G. Y. 1999. Biological control of Bipolaris sorokiniana on tall fescue by Stenotrophomonas maltophilia C3. Phytopathology $89: 817-822$. 